\title{
Natural Law: Practical Reason and Creative Information*
}

\author{
Ley Natural: Razón Práctica e Información Creativa
}

\author{
John FINNIS \\ Emeritus Professor \\ Notre Dame Law School
}

\begin{abstract}
Leaving unstated it's probably many connections with Chinese traditional cultures, it [this paper] seeks to articulate some main theses of the tradition that, owing as much (if not more) to Hebrew prophets as to Greek philosophers, is foundational for a critical appropriation and defence of authentic human rights. Leaving many important human rights unstated, it tries to identify the rational foundations for them all, in nine theses.
\end{abstract}

Keywords: natural moral law, co-participation, Creation, Divine Revelation, human rights, nature.
Resumen: Sin llegar a afirmar que es probable que haya muchas conexiones con las culturas tradicionales chinas, la pretensión que alberga este trabajo es articular algunas tesis básicas de la tradición tributaria (quizás, principalmente) de los profetas hebreos y de los filósofos griegos, que es fundamental tanto para una apropiación crítica como para la defensa de los derechos humanos auténticos. Sin mencionar muchos derechos humanos importantes, pretende indentificar los fundamentos racionales comunes a todos ellos, a partir de nueve tesis.

Palabras clave: ley moral natural, co-participación, Creación, Revelación Divina, derechos humanos, naturaleza.

\section{Natural Law: Practical Reason and Creative Information}

This address has nine main theses, each interspersed with many others:

I. In investigating facts, one finds reasons to choose an honest self-discipline.

II. Deliberating, one finds reasons similarly directing one to other intrinsic goods.

III. Taken integrally, these goods and principles acquire the force of moral precepts.

IV. Those precepts, natural moral law, depict our nature in its flourishing.

V. Nature and natures are best explained by free, intelligent transcendent Creation.

VI. Creation and other gifts past and present deserve our gratitude.

VII. Natural moral law and historical revelation are two channels of information.

VIII. Secular and spiritual communities are distinct and respectfully self-governing.

IX. Natural moral law defines human rights but rightfully extends beyond them.

* This paper was written for and delivered at a conference on Natural Law, Human Rights and Chinese Traditional Culture, held in Beijing by the Law School and the Institute for Human Rights of the China University of Political Science and Law, on 26-27 October 2019. 


\section{IN INVESTIGATING FACTS, ONE FINDS REASONS TO CHOOSE AN HONEST SELF DISCIPLINE}

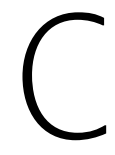

onsider questions, that is, questioning, specifically the first experiences we have had, each one of us, of consciously raising questions of fact, and thinking about possible and available evidence (clues), possible and available answers and explanations. Within that experience, a further set of questions emerged or emerge, alongside the initial question, the one that started the investigation. These further questions were or are something like: What evidence shall I seek, and what shall I ignore and what retain, what shall I treat as the answer - an answer I want, or that others want me to accept, or only the answer which the evidence supports as true? For if I am thinking honestly and carefully, trying to attain a right answer, the truth about the facts that are my initial question's subject-matter, I become aware of two elements of my situation.

One element is the constraints or disciplines of honesty or inner sincerity (about what the evidence is, what really can and cannot be inferred from it), and the demands of diligence or care in considering it and reasoning about it. Those constraints, disciplines and demands formulate themselves in my mind as propositions about what I ought and ought not to do in investigating my question and how to answer it well (honestly and carefully).

The other element is implicit in those «oughts» and «ought nots». It is my freedom to respect them or violate them, deliberately or carelessly. This is a true freedom of choice, choice between alternative attractive, but incommensurably attractive options: to accept inadequate answers that are convenient for my prejudices or my popularity, or instead to carry on searching, if I can, towards answers that, although inconvenient, are (as best I can judge) true, the best explanation of the evidence; and if I cannot carry on searching, not to pretend to myself that untrue answers are true. A choice between the sincere and the insincere, in searching.

Such elements of private experience are among the originating moments in our awareness of the natural law, and of practical reason, and of what practical reasoning is about. The activity I was describing was «theoretical» or factual thinking, investigation of some question of natural science or of history or, later in life, of comparative law or of philosophy... Practical reasoning is about deliberating towards free choice between alternative, incompatible desirable proposals (options) for my choice - alternative desirable states of affairs, sets of ends and means, for me to choose between and then put the chosen option into action to try to achieve the chosen state of affairs. The alternative op- 
tions, in the experience of investigating facts, were (A) my reaching, with ease and applause, an unsatisfactory but popular answer or (B) my discovering, by investigating as carefully and honestly as I ought to, the unwelcome but correct or probably correct answer to the question that I raised and then pursued by the self-disciplined activity of thinking (questioning, evidence-gathering, reasoning, testing, and judging...) as one ought.

The standards or norms that articulate those oughts in propositional form are standards or norms of natural law. In considering how they apply to one's own activity of investigation, one is exercising one's conscience. That is no more and no less than a name for the set of judgments one makes - each one of us makes - about what those standards are, and how they apply to the activity in which I am engaged (in this instance an investigation of facts), or any activity in which I might be engaged, or, looking back, any activity in which I was at some time in the past engaged. We can talk about conscience without using the word «conscience»; it is a word for which we have other words, such as, one's practical reason, one's thinking about, and judging, what one should (or should not) choose - perhaps in general, perhaps here and now - or about what one should have chosen at some time in the past when one chose not to follow one's conscientious judgment and instead to adopt some other attractive option like a dishonest or careless but comfortable resolution of the investigation.

These standards or norms are internal to one's thinking. In that sense, they have their origin in one's mind and thought. But in another sense, they stand over against one's thinking, as a critique of that thinking whenever it seems likely to deviate from them. One should not judge them to be mere emanations from one's psyche, like a dream or fantasy, nor treat them as a passing thought. They stand over and constrain one's self, one's subjectivity, as objective disciplines for coming to know, or to know more, about what is not at all a product of one's thinking, namely (1) the whole vast world of realities that are what they are independently of one's thinking, and (2) the whole domain of logical requirements of valid, non-fallacious reasoning, and (3) the whole domain of techniques and technologies that work, successfully, for those who understand and apply them, but not for the ignorant, the daydreamers and the undisciplined, and (4) the whole domain of choices and actions that respect practical reason's norms and principles for good human choices. These are norms whose initial constraints, disciplines and demands upon me relate directly to the good of truth and knowledge of it. They tell me, directively, what I need to do, must do, with honesty and care, honorably, to reach the truth in any and all these four domains. 


\section{DELIBERATING, ONE FINDS REASONS SIMILARLY DIRECTING ONE TO OTHER INTRINSIC GOODS}

Truth (and knowledge of it) is not the only basic human good. It is not the only good that I can and do, effortlessly, understand to be good not simply or only as a means to other good states of affairs and ways of being, but as - also and more basically - intrinsically worthwhile, a human good is to be pursued and respected in my choices and actions for its own sake: good not primarily as an object of thought, or «ideal», but rather, as embodied in actions and actual states of affairs, as elements of the wellbeing, the flourishing, of real persons, myself and others.

The proposition that truth and knowledge of it is good and worthy of pursuit is not the only first principle of practical reason, that is, of thinking about what to choose and do. Other equally primary, equally basic, equally obvious first principles include:

- the good of human life and health;

- the good of friendly association with other human persons in many kinds of good and needful association;

- the good of mastery, ludic or artistic or purposeful, over matter;

- the good of marital commitment to another person in which, with me, can, as father and mother, procreate children whose conception supervenes on marital intercourse that is expressive of our commitment to each other as wife and husband, children to whose nurturing, upbringing and education we are committed as father and mother without limitation of time;

- the good of associating in awe, gratitude and hope with the creative mind and will to which this address will soon be turning;

- and the good of choosing and acting upon immediate and long-term priorities among these goods - and among alternative ways of respecting and promoting them - in a reasonable way: the good of practical reasonableness for its own sake.

That these are goods for any human person is in each case a truth that we do not invent, but find, discover, come to understand when we attend to and consider the possibilities that lie open to us for our choice and action. In each case, the principle that identifies and directs us to one of these intrinsic goods is a principle we find, not invent. Each of these principles' directiveness, its normativity for our deliberations towards choice, is not a directiveness that we chose, or that someone or some group chose for us, but a truth that we 
discovered $^{1}$ when we considered these possibilities and the alternatives to them: disease and death; ignorance, confusion and falsity; egotism and disharmony; passivity and indiscipline; sterility and the cessation of our humankind; indifference to the origins and destiny of the cosmos and of our own consciousness, freedom of choice and responsibility; arbitrariness and subjection to passions rebelling against or enslaving reason...

Thus, in the way we come to know them, and in the way they wait to be discovered and when discovered are directive and normative, these goods or needs, like the corresponding principles of theoretical (fact-seeking) reason, are natural, and their normativity is already a kind of «natural law». That is to say, they constitute a set of directives internal to our inmost, most personal thinking, not inventions or projections or constructs of that thinking but pointers towards ways of life and states of existence that align us to reality and truly do constitute the essential elements of human flourishing. And this is the case even when the discovery of them is implicit and is expressed indirectly and in another language. First principles can do their directive work, in thought and deliberation, without being articulated «clearly and distinctly». One usually does not work forward from them into morality and culture but rather discovers them reflectively as the principles that are at the root of an adequate explanation and justification of any of the morally sound ways of life that one has become aware of.

\section{TAKEN INTEGRALlY, THESE GOODS AND PRINCIPLES ACQUIRE THE FORCE OF MORAL PRECEPTS}

Their normativity is real and indispensable. But it is not yet moral normativity. These principles of practical reason provide moral thinking with the source of its normativity, of moral normativity, and with much of its content. But the sense (intelligibility) and force of moral principles, precepts, considerations, and conclusions is given not by any one or more of the first practical principles considered one by one. That intelligibility and force is supplied by taking the directiveness in each of them together with all the others integrally, that is to say without sub-rational limitations, especially sub-rational limitations exclusively to myself or exclusively to some arbitrarily selected subset of human persons.

1 See the discussion of questions in FINNIS, J., «The young child's questions», Reason in Action: Collected Essays., vol. I, Oxford University Press, England, 2011, pp. 1-12. 
The integral directiveness of the set of first practical principles point me towards the fulfilment or flourishing of all human persons and groups. They do not direct me to make that flourishing of all human persons and groups a direct object of my choices, as if it were some feasible goal of purposeful disposition of means. Instead, their integral directiveness is articulated in each and all of the reasonable ways of respecting persons, and all reasonable prioritizations of care and effort, that we find stated in the principles and precepts of justice and courage and temperance. These are moral principles and precepts, informing us how we need to deliberate, choose and act if we are to be practically reasonable, just and decent human persons. Morality is the set of requirements of respect for humanity, because humanity is what we are respecting and promoting and duly loving when we keep our choices compatible with integral human fulfilment.

\section{THOSE PRECEPTS, NATURAL MORAL LAW, DEPICT OUR NATURE (HUMANITY) IN ITS FLOURISHING}

To the extent that they live with fidelity to true moral precepts, in choice and in action, human persons are - unless circumstances are most adverse flourishing instances and manifestations of human nature. This is human nature, humanity, not simply in its capacities, radical, developing or developed, but in its flourishing. That is, I think another meaning of «humanity». Many of the moral precepts are precepts of justice. But justice concerns what I owe to others, and I also have duties to myself. «Love» - that is, wish the good of «your neighbor as yourself».

Some of these duties are negative: not to try (intend) to destroy or damage any basic human good in any person, not to choose kinds of acts that are contrary to the good of marriage, not to divide oneself by making one's assertions lies. Others are affirmative (positive): to help others in their needs, above all by living out a coherent set of responsibilities to one's family and other dependants, to one's close neighbours and to one's fellow workers and one's economic or other vocational cooperative organization, and to one's fellow-countrymen, and to all human persons anywhere whom one could help or keep safe by care or contribution of work or resources compatible with my prior responsibilities of the kind I have just mentioned.

The negative duties of justice and respect for human persons can be, in morality and in law, exceptionless. The affirmative duties or responsibilities 
are always more or less contingent upon, and proportionate to, the circumstances - that is, to other competing responsibilities. Assessing these responsibilities may require careful attention to the certain or probable or really possible side-effects and other consequences of my choice and action. But the morally required assessment can never be reasonably guided by a «principle» that what is morally right is what maximizes the overall net of pre-moral good. Many kinds of incommensurability make that theory of morality unreasonable. I will mention only one illustration, in which only one of the basic human goods is at stake (I take and adapt the example from Bernard Williams in his debate with J.J.C. Smart about utilitarianism).

In the open-ended life of an individual or group, consider the consequences of choosing, for example, to try to kill one innocent (non-threatening) person as part of a deal with terrorists to save 19 of the 20 they were about to kill; or the consequences of choosing to kill 19 as part of a deal to save one of the 20 whom the terrorists were about to kill. The consequences extend far beyond the saving of the 19, or of the one: they include the effects of the acting person becoming a certain kind of person, one ready to kill innocent (non-threatening) persons when that seems to him likely to have better consequences. The consequences of him becoming that kind of person, acting or ready to act on that sort of policy, are incalculable. They are likely to be very bad, especially if his action, his policy, and his character are approved by others and become part of their characters and attitude to life. So, a consequentialist morality of trying to sum up and net off the pre-morally good consequences of my actions against the pre-morally bad is very unreasonable. A sound morality has firm precepts (and corresponding duties and rights) against intentionally killing, commit adultery and other contra-marital acts, and perjury, to accompany its many affirmative precepts requiring actions, productive or precautionary, seeking to achieve good consequences within some field or fields of responsibility that can reasonably be considered part of the particular acting person or group's morally-shaped vocation or commitments, narrow or relatively wide.

That is the briefest summary of the natural moral law, or moral natural law. Anyone ready and willing to act on and in accordance with those precepts, affirmative as well as negative, has the moral virtues, the working-in-practice of the natural good of practical reasonableness (that Aquinas called the bonum rationis, the good of being reasonable) which when fully embraced is the moral virtue of practical reasonableness that the Greeks called phronesis and the Romans and their Latin-speaking successors prudentia. 


\section{NATURE AND NATURES ARE BEST EXPLAINED BY FREE, INTELLIGENT TRANSCENDENT CREATION}

So: practical truths that we find and do not make, do not invent, do not produce, are understood in the form of practical propositions. Those propositions, if followed out in their implications when taken all together, direct us that our actions favor and respect the goods in all human lives. These directives are more specifically normative and directive than when or if the propositions first were understood, one by one, as directing us to the good of truth, the good of life, the good of friendship, and so on. That was the framework of what I have said so far this morning.

Now consider the fact that we have these powers of understanding and reason, and that these powers or capacities enable us to understand and affirm these and many other truths about our responsibilities. Consider at the same time the fact that those powers and capacities enable us to also understand and affirm the countless truths and realities of logic, and of nature itself - the universe and all it contains - insofar as it exists, as it massively does, independently of our understanding. Each of those great facts - about our power of understanding and about the truths and realities and goods it enables us to discover (not invent) - is a great source of wonder, a real marvel, a supremely interesting topic of inquiry and source of questions seeking explanations of these facts and realities.

The progress made in the twentieth and early twenty-first centuries in the natural sciences both of biology and physics (most recently of nano-physics) and in the natural history of the universe (paleontology), has shown with ever greater clarity that the explanation developed first by the prophets of Israel was an explanation greatly superior to the explanations developed by, for example, the Greek philosophers. Skeptical empiricists blocked fruitful empirical science by postulating or proposing that everything is nothing but material particles in random motion, eternally. More critical thinkers made vast progress by hypothesizing and affirming intelligible form(s) (as in design) to explain the motions of matter and presume a design-like intelligibility of substances, in which matter is dominated and shaped by form into substances in their various kinds or species or natures. But progress remained impaired by continuing assumptions about the eternity of the world and about the divinity of at least some stellar bodies. Never did the ancient Greeks break through the Hebrew prophetic insight that the universe, with its time, was created out of nothing, and so did not exist eternally but had a beginning, a genesis, and is not divine and contains no part or share of the one eternal God, who utterly 
transcends the universe and is «in it» (and in every one of its parts) only as its primary and transcendent cause, effective through secondary causes in the way that St. Thomas Aquinas worked out against Islamic theologians for whom the sovereignty and free will of God excludes the possibility of investigating and predicting natural events and processes. No, said Aquinas, everything that happens - human free choices aside - is totally the result of natural causes whose pattern and effects can all be scientifically investigated (causes whose interaction in particular events includes, of course, a large measure of contingent coincidence and thus many causal events), while at the same time everything that happens is totally the result of transcendent divine causality ${ }^{2}$. Here we see an important aspect of the meaning of «transcendent»: its primary causality does not subtract from or impair in any way the completeness and sufficiency of natural («secondary») causes and their natural effects. Totally by primary causality and totally by natural secondary causality.

The contemporary study of sub-atomic processes, of molecules great and small, and of cells and organisms converges in every one of those fields on the finding that what we call matter, and may reasonably continue to call matter, is at bottom no more and no less than processes or events dominated by information, by pattern, form, and intelligibility. And the history of the universe, now well and verifiably understood as initiated by that astonishing singularity, that sheer beginning, popularly called the «Big Bang», shows that the universe's creation involved no more and no less than the creation of the type of energy we call light and, along with light, the information which confers about light-energy, its forms, its directions, its substances - first elementary and then more complex but never infinitely complex: the number of chemical elements emergent from imploding stars is rather small: below 100, that can be extendable artificially to a number still well below 200 .

And since the Big Bang is the initial union of created light and created information, we can see how far the prophet or prophets of Israel who composed chapter 1 and the first four verses of chapter 2 of the book called Genesis were successful in understanding the mind and freely chosen action of the

2 Summa contra Gentiles III, Ch. 70 [para. 8]. On the matters mentioned in the present and the next paragraph of this address, see FINNIS, J., «On Anscombe's 'Royal Road' to True Belief», American Catholic Philosophical Quarterly, vol. 90, n. 2, 2016, pp. 347-68; also published as «Body, Soul and Information: on Anscombe's 'Royal Road' to True Belief», in Luke Gormally, David Jones and Roger Teichman (eds.), The Moral Philosophy of Elizabeth Anscombe, St Andrews Studies in Philosophy: Imprint Academic, 2016, pp. 263-88. 
Creator when they wrote: «And God said»- notice: there is the information, put (like speech) into a form distinct from the speaker, and communicated «Let there be light, and there was light». People used to be puzzled by the fact that in Genesis 1 the light is created several «days» before the sun. But that, as we now know, is a sober truth about the chronology of creation as we now know it from late $20^{\text {th }}$ century cosmology.

The book called Genesis did not intend to give a natural-scientific account of the origin of the universe. But it did intend to repudiate myth and to give, instead of myth, a historical parable. A parable, in Hebrew, a mashal, intends to make a true comparison between the simple, concrete, imaginable elements of its story and certain realities of the human situation that are not recounted but evoked by that story. In a historical mashal, certain real sequences and causes and effects that occurred historically are evoked and reported, not directly but indirectly. An example of a historical mashal is the parable that was told to his disciples by the Rabbi from Nazareth as he approached Jerusalem for the last time before his execution, the parable of the wicked vine growers or husbandmen or tenant farmers. For that parable intended to and did convey decisive elements of the true bistory of Israel - the history, in bare outline, of its dealings with its prophets and eventually with this prophetic Rabbi, the Teacher from Nazareth, the parable's teller himself.

The three documents in which this historical parable appears, Matthew, Mark, and Luke, are not parables or mashalim, not even historical parables or mashalim. They, like their complementary document fohn, are historical statements conveying what various eyewitnesses remembered, almost all about what that teller of parables and moral truths actually said, and did, by healings and other signs and wonders before and after his arrest, trial and execution, over the preceding period of three and a half years, in the Roman imperial province of Judea and the client-kingdom of Galilee and Perea, and some of the neighbouring territory in the empire.

\section{CREATION AND OTHER GIFTS PAST AND PRESENT DESERVE OUR GRATITUDE}

The discovery - not an invention or projection - of the gigantic fact of Creation by an absolutely transcendent, eternal, simple, unchanging mind enables us to understand natural law - first practical principles, master moral principle, and general and specific moral precepts - in a deeper and more 
adequate way. Now the fact that we understand those precepts and principles, and thus that law, can itself, that fact, be understood to be a kind of sharing, participation, in the mind of the Creator.

The choice to create, and to create this very universe rather than any of the countless possible alternatives, is a choice which involves no change in the eternal existing and self-understanding of the Creator but rather the greatest possible change in the created, the universe of creatures - the change from nothing to something and this something. That choice was carried into effect by imparting the information that establishes the various natures and all the natural activity of all those creatures. The cumulation of natural scientific information and understanding makes it now apparent that that communication of information was not complete in an all-at-once initial singularity but has been progressive over the approximately 14 thousand million years since that singularity. For that initial singularity can hardly have contained within it all the information which we see operative in two subsequent, not quite so instantaneous singularities: the emergence of life, each living cell, however rudimentary, being more complex than the entire universe of billions of galaxies that preceded the first cell; and the emergence of rational animals capable of freely choosing between intelligible alternative options or proposal for intentional action.

Indeed, the nature of a living animal which a person is, who can ask questions about anything - about the universe and creation, and about what to do with his or her own life, as a whole or this morning - is a nature so different from that of all other animals and inanimate creatures that it has been reasonable, even before the discoveries of modern science, to infer that it is by a kind of individualized, special act that the eternal and unchanging Creator imparts to each human being, one by one, the information, the soul, that is the very form and actuality of his or her human life. When that soul's informing of matter has developed this new human being's radical capacities (the capacities or potentialities that came, actually but entirely undeveloped, with or in his or her ensoulment), and developed them to such a degree that his or her own bodily life can sustain consciousness, thought and deliberation, then he or she can actually (not merely potentially) do all that I have been recalling this morning - all the questioning, understanding of opportunities and dangers, consideration of alternatives for action, understanding of the constraints, not invented or self-imposed but found and normative, of honesty and care in investigation, reflection, communication and deliberation.

And the natural response to discovering what one has thus been given, ultimately from notbing, is gratitude. That gratitude for Creation is an impor- 
tant element in the enhanced intelligibility and enhanced normativity of the natural moral law.

Indeed, even before the discovery of the transcendent Creator, natural gratitude is a significant element in an adequate understanding of the principles and precepts that one finds and does not invent, and in an appropriate response to them. For the I who discovers the intelligible goods of life, knowledge, mastery over matter, friendship, and marriage, and who discovers the normativity of these goods as goods for me but equally for anyone like me - that is, for any human person - also discovers myself to have been the child of parents who brought me into being (Only much later does one discover that that bringing to be should result from an act expressive of the two parents' free commitment, a commitment both to each other in marriage and to any child whose coming-to-be might supervene upon that act (either as its intended effect or as an acceptable side effect of it). But even early on I know them as parents who by themselves or through their substitutes provided me with the means to live and grow and become the beneficiary of all the goods that I possess and share in and have the opportunity to possess, and share in and share out to others, in the open horizon of my future life. And I discover, too, that the language and all the other cultural riches of my people, resources like houses and harvests and hospitals and highways that I find (or can hope to find) available to me - and cannot and do not myself invent - are all, for me, gifts to appreciate and be grateful for. That understanding of what I owe to others, of my debt to those others (as also to the Creator of all), is intrinsic to an adequate understanding of what it means to articulate, acknowledge, propose or assert a moral ought.

And that ought is, once again, natural in the sense that it is fully reasonable, the outcome of correct understanding of our nature, our situation and its opportunities, to which we are directed, first by the first principles of practical reason and then by their reasonable interrelating - with each other and in the lives of others than ourselves - through the ideal or master moral principle of integral human fulfilment.

\section{NATURAL MORAL LAW AND HISTORICAL REVELATION ARE TWO CHANNELS OF INFORMATION}

By bringing Creation, after many billions of years, to the point where it could fittingly include bodily persons, the Creator introduced more than one new kind of reality into the universe. 
One new reality was the natural law in the sense that I have been discussing in this address: the principles and precepts that inform and direct, mind to mind, by being understood and freely accepted as normative guides to rational and reasonable choices and the actions that execute those choices. «Natural law», in that meaning of the phrase, is different from what we call the laws of nature. For laws of nature operate throughout the universe, informing and directing all its activities and substances, including our own character and dynamisms as animals, without having to be understood at all by the substances whose being and activity these laws inform and direct. But the natural law that works through understanding, directing choices without determining them or eliminating or even weakening the capacity to choose, immorally, against them, is a reality additional to the laws of nature.

A second new reality that in our universe became possible with the creation of human persons is a standing human capacity making possible the direct communication of information not simply from mind to mind but from person to person, by historical acts of communication of the kind that we call divine revelation. The superior understanding of the universe that emerged in ancient Israel seems have to have been gained in some considerable measure by this means, though the prophets, at least some of them, may have been inspired precisely when engaging in enquiry and reflection more or less philosophical. Among those prophets is the great lawgiver who announced to those people a ten-proposition law which he did not invent, but also did not find by enquiry and reflection, but received by interpersonal communication of information when he was away from all his fellowmen on the mountain in southern Sinai, east of Egypt's Red Sea.

Since that time, especially since that set of Ten Commandments was ratified and distinguished from all other Mosaic legislation by the Rabbi from Galilee and by Peter and Paul and his other close followers in the Assembly at Jerusalem in 49 A.D., it has become possible and necessary to speak of natural law in a new sense: natural law as distinct from divinely revealed law. Natural moral law can be known by people of all times and places by natural rationality in reflection on ourselves, our neighbours, our opportunities and so on and so forth. Revealed moral law can be known only by those to whom there has been handed on the information that was, in fact, imparted, mind to mind and person to person, in some historically located activities of divine revelation, for example to Moses, and for another and decisive example in the teaching and example of the Rabbi from Nazareth. The content of this revelation should be distinguished from the fact of revelation, which is a fact that, in relation to rev- 
elation's decisive phase of revelation - adding to but confirming the authenticity of the earlier phases - is open to the investigations of enquiring natural reason. Such an investigation, as is implied by this address's first thesis, seeks truth about events and intentions, like in a criminal investigation or truthful biography, in order to judge, with care and honesty, honorably, whether there was or was not in those days and months an authentic communication from the divine and personal Creator.

As I have already indicated briefly, the distinction between natural and revealed law needs to be understood with care. The community of believers founded by the Rabbi and his close followers the apostles teaches, perhaps uniquely, that the propositional content of the revealed moral law is the same as the content of the natural moral law accessible to people who have not heard or believed the revelation. Revelation does not subtract any of that content of natural law, but rather gives it a new clarity and certainty.

Of course, beyond the domain of natural moral law, revelation offers a wealth of new information, information that could never have been discovered by enquiry into and reflection on the natural world as it came from the pre-revelatory acts of the Creator and as it exists in accordance with the corresponding laws of nature - of physics, chemistry, biology and so forth. The new information concerns, above all, a new singularity, a new, final and supernatural stage of Creation. It tells us that the Creator somehow will take, beyond this universe, into divine existence and life itself, all those human persons who explicitly or implicitly choose to participate in this final stage of Creation, the Creator's «kingdom» coming and to come (including, it seems, all who, without ever hearing this good news, had or have hearts - wills - equivalently open to the divine will). This is indeed a stage of Creation, and an opportunity, beyond what is naturally foreseeable. So how does it relate to the natural law that is my subject this morning?

In the documents of this revelation, the course of human history and destiny is depicted in various ways. One of them is by depiction of three gardens. In the historical parable of chapters 2.4 through 3 of the book of Genesis there is the garden «in the east» in which the first truly human, rational, personal creatures lose an immortality (and undying intimacy with the Creator) that was not yet given to them and yet was somehow in prospect as a fruit not yet eaten of a Tree of Life divinely planted in the midst of the garden alongside a Tree of Knowledge of Good and Evil, a forbidden knowledge or experience of choosing and enjoying whatever one wills, even what one knows to be against the supremely wise will and intention of the 
Creator of all goods including all true knowledge. It is in parable a history of the willful and personal assumption of responsibility, a choice by each individual, partly (as we ought to choose) out of friendship and trust in each other, and yet wrongfully, because chosen (as we never ought to) out of disbelief in the wisdom and goodness of the Creator's word and precept. That true account by parable of the ever-repeated history of human wrongdoing freely chosen is placed at the beginning of the revelation's Library $(\mathrm{B} i \beta \lambda \imath \alpha)$ as a prophecy that the new, final and supernatural stage of Creation must await the gradual moral education of human families and societies, and then a new divine gift.

And the second garden, in revelation's depiction? The final stage of Creation awaited, above all, the intervention in history of a human being whose life, from its very inception at conception, has been assumed into the Creator's divine life and thus has been and is the life of a person who is both truly human and truly divine, a single person who is double in nature, life and will, and who in his agonizing personal human trial of conscience and will, at night in the garden below the eastern wall of Jerusalem in early April $33 \mathrm{AD}$ - in full knowledge that apprehension and execution awaits him within a day if he remains faithful to his mission - chooses that fidelity (and accepts, as side-effect, its lethal consequences). The words in which he articulated that choice - words actually overheard by one or more of his disciples, or later recounted by him to them ${ }^{3}$ - express his reversal of the fault and separation first committed in the earlier «garden in the east»: «Father... not what I will, but what you will» ${ }^{4}$.

And then, in the very last scene portrayed for us in the Library of divine revelation, there is, in the new Jerusalem, a whole garden of Trees of Life planted on either side of the river of the water of life that flows through that holy city «come down from heaven». ${ }^{5}$ A part of what that parable-vision communicates is the immortal life available to those who are willing to do the will of the Creator to the end, and not available to any who loves or does falsehood $^{6}$. The correlation between the will of the Creator and the natural

3 Vid., Luke 24. 44-46; Acts 1. 3-5.

4 Mark 14. 26; Matthew 26. 39 and 42; Luke 22. 42; and see fohn 4. 34; 5. 30; 6. 38.

5 Revelation 22. 1-2;21.2; in the whole Bible, the last previous reference to the tree of life was in Genesis 3. 24. In Rev 22. 1-2 the reference to the garden is pictorial, not verbal.

6 Rev 22. 3, 14-15. 
moral law is as close and tight as the correlation between defying the natural law and «doing falsehood».

The other part of what is conveyed by the parable-vision of the «new Jerusalem» - the part that perhaps is more certainly intended by whichever $\mathrm{John}^{7}$ was its human author - is the separating out from the old Israel (and old covenant between God and Israel) of the new people (and new covenant), the people of the new ekklesia, the assembly, the church established on the foundation of the Twelve who were the closest followers of the Rabbi and eyewitnesses of his preaching, his death and his rising, bodily but already transfigured, from among the dead. This new assembly has now the custody of the revelation and of its library or biblia, and of the storehouse of helps to all people everywhere to participate in the new creation, the last and supernatural (miraculous) phase of Creation which will continue, without extinction of persons, into God's eternity even as, and after, the old Creation begun by the Big Bang succumbs as it naturally must to entropy, loss of information, and finally to inertness if not extinction.

\section{SECULAR AND SPIRITUAL COMMUNITIES ARE DISTINCT AND RESPECTFULLY SELF-GOVERNING}

A part of the revelation, closely based on the famous saying of the Rabbi about what does and does not belong as of right to «Caesar», is the following. Civil or political or state power and authority, on the one hand, and spiritual or ecclesiastical authority and power, on the other hand, are distinct, and indeed separate - separate communities each complete in its own way - such that under ideal conditions of discovery everyone would be a member of both (though membership of the ekklesia is entirely voluntary), but neither of these complete communities is entitled to be the governing internal manager of the other.

So, the remainder of this address sets aside the revealed information about the new creation, and the ecclesiastical community organized on its basis and to promote it. It will speak only of civil societies and of the political community, the state with its governing organs and law, and of the rights and

7 Vid., Rev 1. 4, 9 (quite possibly John who was called Mark: Acts 12, 25; 13. 5, 13; 15. 38-9; 1 Pet. 5. 13; 2 Tim. 4. 10; Col. 4. 10; Philemon 24; perhaps also 2 Cor. 8. 18-21). 
duties that the state's government and law are morally authorized to promote, protect and vindicate by state law.

But before we set aside that ecclesiastical community, complete in its own right and in its own way, one should not fail to notice that its existence and legitimate authority helped to cast doubt upon Plato and Aristotle's belief that the moral, natural law authority of state law and government to make and enforce positive laws extends to laws which are parental or, in a modern idiom, «paternalistic». A «paternalistic» law prohibits specified private activity in the hope that the prohibition will deter, dissuade or convert some or many or all who are tempted to engage in such activity by their own free and adult choice, and thus rescue them from damaging themselves, morally at least, by engaging in conduct of the kind specified in the law as «harmful». A sound natural law theory of governance of states in modern conditions will differ sharply from Aristotelean theories which presuppose that there is only one complete community, the political, and that its role is to bring each and all its adult citizens to complete fulfilment and moral virtue, and which therefore treat as a legitimate end of government and legislation the saving of people from the moral, spiritual harm each inflicts on himself or herself when he or she chooses to engage in acts that are harmful to him or her and not, or not directly, to others. For a sound natural law theory - one such as Thomas Aquinas developed knowing that there is another, non-political community which has the role of bringing all its members and ideally all the state's citizens to complete fulfilment and virtue - will judge that the state's government and law, since it does not have that role, properly exercises coercive jurisdiction only in relation to acts and words which impact negatively not, or not only, on the acting person, but on persons other than himself. Government and law, in such a theory, should be informed by a true understanding of natural law and indeed, if possible, of the truths of supernatural revelation and destiny. Such knowledge will assist it in many ways, without conferring on its jurisdiction to enact and enforce laws prohibiting purely private self-regarding, self-affecting acts or omissions. That, as I say, is the thesis of Thomas Aquinas ${ }^{8}$, often misunderstood by very many of his followers over the centuries, who assumed he was more completely a follower of Aristotle than what in fact he was.

8 FinnIs, J., Aquinas: Moral, Political and Legal Theory, Ch. VII., 2-6, Oxford University Press, England, 1998. 


\section{NATURAL MORAL LAW DEFINES HUMAN RIGHTS BUT RIGHTFULLY EXTENDS BEYOND THEM}

Precepts of justice direct us to abstain from acts and omissions that injure another person or persons. Precepts of justice, Which Aquinas already held, have as their object, their point and rationale, the other person or persons' right, that is, what the other person is entitled to from the person who has the duty - a duty which (using language that is not Aquinas's) we can therefore say is correlative to that right. So (Aquinas goes on) the appropriate definition of justice is the disposition to give or render to another or others their right or rights. That is already, essentially, the modern conception of a right: to have a right is to be the beneficiary of a duty imposed by some law or principle, whether of state law or of natural law.

A later idiom for saying the same things speaks of the natural rights that natural moral laws entail, and a still more recent idiom for the same propositions talks of buman rights. If human rights are formulated or understood without strict regard to the individual duties that are their correlatives, they are merely programmatic assertions of a benefit or interest that is claimed to be important, yet claimed without sufficient care to specify a correlative duty, or to specify who has such a duty. Talk of human rights is important and true only when it is accompanied by care to identify the person or persons who has or have the correlative burden - of doing or abstaining from doing something specific, the doing or omission of which affects a specifiable individual or class of individuals in a manner, and to a degree, that is contrary to some applicable precept of true morality.

The clearest and most certain human, natural, natural-law rights are those in which a basic human good is closely and directly at stake, that is, where there is a clear and certain duty not to choose to destroy, damage or impede a person's participation in that good. The most obvious examples are the right to life - not to be intentionally killed, or to be mutilated (as distinct from undergoing amputation for the sake of one's survival or overall health) - and the right of A to marry B who is someone willing to marry A and who together could engage in marital relations, relations on which might supervene a child whose true parents would be $\mathrm{A}$ and $\mathrm{B}$.

But there is important moral (natural-law) truths which are not immediately expressed as natural or human rights. Important examples of these truths relate to the desirability and suitability of appropriating parts of the world's surface to specific peoples to be their territory to the exclusion of other peo- 
ples and persons save by leave. The national or state territory of China, or of the political community known as the United Kingdom, are examples. The desirability and suitability of that kind of appropriation is closely similar to the desirability and suitability of appropriating parts of a political community's resources to particular individuals or families for them to control manage, develop, use and enjoy the produce within a framework of law. Such law, if just, directly or indirectly ensures that while these owners or lawful possessors have the initiative and priority in control, and a right of exclusion of others, their rights are subject to a duty of sharing of the fruits or profits whenever these exceed a level appropriate broadly to their reasonable vocations as individuals or families, and a duty of sharing in severe emergencies, and a liability to be expropriated for the purposes of public works, with just compensation. Legally defined rights of property have a strong relevance to the wellbeing of everyone on the territory, and often to the wellbeing of sort of dependant persons outside the territory. But no one comes into existence with a prior right to some specific part of the world's or their country's resources. So it is difficult to identify a natural or human right to private property, beyond a generic right that one's rulers and fellow citizens deliberate and choose with responsibility, honesty and care about the advantages and costs of adopting and maintaining a stable legal order of property rights aligned to the genuine interests of families and local communities, not forgetting the national and international interest in the development and resultant relative prosperity of all who can benefit from the efficiencies of management and productivity that very regularly tend to result from stable legal appropriation to private persons or associations.

Like the genuine benefits to everyone that tend to result from the stable national sovereignty over defined territory, in preference to a cosmopolitan right of every individual and group to migrate to any part of the world at their choice, these benefits of legal appropriation of resources to nations, and within nations to persons and other entities, are not merely material or measurable as Gross National Product, family wealth, or the like. They include also, and very importantly, the benefits and dignity of self-direction or self-government, the non-servile status of independence over time, such that the fruits of past care and cultivation and culture are cherished not for hoarding but for the benefit of present and future generations. This cultural capital, to call it so, includes expectations and tolerances, languages and mutual intelligibility, works and modes of literature and other fine arts, accessible and honest history of one's family, one's neighborhood, one's worshipping community, one's edu- 
cational institutions, one's regiment, one's country, and indeed humankind. It should be a cultural capital lived in by a people open to true information, including information from the Creator whose natural creative information has made and continues providentially to make all these good things possible and attainable.

That transcendent providence in its working out proceeds according to standards and norms that we do not now know, and includes obstacles, deficiencies, and ills the point of which we do not understand. But the information that we do share in by natural reason, clarified and supplemented by historically given and authenticated revelation, gives us reason to think that, in the providential wisdom of the Creator of nature and of our natures, all will prove to have been for the ultimate benefit of each one of us, in diverse ways, and if not now then in His eternity, which each of us, responsible for his or her own free choices, faces one by one. 